\title{
Sustainability Index of Solar Power Plants in Remote Areas in Indonesia
}

\author{
Dwipayana $^{1} \cdot$ Iwa Garniwa ${ }^{2} \cdot$ Herdis Herdiansyah ${ }^{1}$ (D) \\ Received: 20 November 2019 / Accepted: 6 December 2020 / Published online: 3 January 2021 \\ (C) The Author(s), under exclusive licence to Springer Nature Singapore Pte Ltd. part of Springer Nature 2021
}

\begin{abstract}
Energy is an inseparable component in human life in every aspect. However, many regions cannot utilize energy sources to support their daily activities, so there are several breakthroughs made by the government, including the construction of solar power plants in remote areas. Some challenges arise because is Solar Power in remote areas sustainable? This research analyzes the sustainability of Solar Power in remote areas as environmentally friendly energy built by government funds (State Budget). The research location is in Sukarasa Village, Bogor, Indonesia, a remote area that has Solar Power as a source of community energy. The analysis was carried out by analyzing the Solar Power sustainability factors such as technical, environmental, social, and economic factors). The results of the analysis of Solar Power sustainability in rural areas using the or Multi-Dimensional Scaling (MDS) method in the form of a kite diagram. Of the four dimensions of sustainability, the highest sustainability index values are the environmental dimension; social dimension; technical dimension, and economic dimension of having a less sustainable status, while the environmental dimension is the only dimension of sustainability that has a fairly sustainable status. These results indicate that solar power plants in remote areas are quite sustainable, but there needs to be a mechanism for periodic maintenance and community participation in managing this Solar Power.
\end{abstract}

Keywords Sustainability index $\cdot$ Solar power $\cdot$ Remote areas $\cdot$ Energy $\cdot$ Sustainability

\section{Introduction}

In Indonesia, differences between demand and supply of electricity, resulting in shortage of electricity supply in some areas, especially areas outside the electricity system of PT. Perusahaan Listrik Negara (PLN) Java-Madura-Bali. In 2017, there are still 7.2\% of households in Indonesia that have not received access to electricity. Government has continuously developed renewable energy power plants, especially in remote areas to increase the electrification ratio and as an effort to reduce greenhouse gas (GHG) emissions. However, since 2011, 10\% of the total Solar Power units that have been built by the government have been damaged.

Herdis Herdiansyah

herdis@ui.ac.id

1 School of Environmental Science, Universitas Indonesia, Jakarta 10430, Indonesia

2 Electrical Engineering Department, Faculty of Engineering, Universitas Indonesia, Depok 16424, Indonesia
The potential of solar energy in the western region of Indonesia is $4.5 \mathrm{kWh} / \mathrm{m}^{2} /$ day, while the eastern region of Indonesia is 5.1 $\mathrm{kWh} / \mathrm{m}^{2} /$ day, with an average in Indonesia is $4.8 \mathrm{kWh} / \mathrm{m}^{2} /$ day (Deputy Strategic Plan for the Coordination of Energy, Natural Resources and Environmental Management [1]). This encourages the government to continue to build renewable energy power plants, especially in remote areas to increase the electrification ratio. The selection of the construction of renewable energy power plants in remote areas is also carried out to replace the use of types of electricity generation other than renewable energy in remote areas which cause GHG emissions and have a negative impact on the environment. The type of renewable energy power plant that is mostly built in remote areas by the government is Solar Power. This is because the potential of solar energy is owned throughout Indonesia, while the potential for other renewable energy such as water, wind and geothermal energy is not necessarily possessed in all remote areas.

Until now the central government through the Directorate General of New and Renewable Energy and Energy Conservation, the Ministry of Energy and Mineral Resources has built 494 units of solar power plants with a total capacity of $21,548 \mathrm{kWp}$ for 63,193 households spread 
throughout Indonesia (Renewable Energy and Energy Conservation Statistics [2]). However, there are Solar Power that can no longer operate optimally. Since $2011,10 \%$ of the total Solar Power units that have been built by the central government have been damaged [3].

Indonesia as a country located in the equatorial region has the potential of solar energy of $4.5 \mathrm{~kW} / \mathrm{m}^{2} /$ day [4]. Based on this, Solar Power is suitable to be developed in Indonesia, especially in remote areas that have no electricity. There are five main components in Solar Power, namely photovoltaic modules, solar charge controller, inverter, and batteries.

The energy provided by the sun directly can be utilized in the form of heat (thermal energy) and as electricity through photovoltaics. With photovoltaic cells, sunlight on these cells can be converted directly into electricity. Meanwhile, to utilize thermal energy, the incoming sunlight needs to be concentrated and captured heat [5].

Afgan and Carvalho [6] conveys an assessment of the sustainability of an energy system or a power plant can be done using four indicators, namely:

1) Resource Indicator: Indicators of resources include: fuel, stainless steel, copper, and aluminum, which are the raw materials in a power plant.

2) Environmental Indicator: Environmental indicators consist of four elements, namely carbon dioxide $\left(\mathrm{CO}_{2}\right)$, nitrogen oxide $\left(\mathrm{NO}_{\mathrm{x}}\right)$, sulfur dioxide $\left(\mathrm{SO}_{2}\right)$, and waste generation (see Table 1 for more details).

3) Social Indicator: Social indicators reflect social aspects including: labor, quality of life of the community, and benefits to the community.

4) Economic Indicators: Economic indicators are based on effectiveness, investment costs, and energy prices.

Renewable energy power plants, especially Solar Power have been widely used as sources of electrical energy in remote areas, both in Indonesia and in other developing countries. [7]) said that the fulfillment of electricity needs in remote areas of Indonesia is still largely dependent on the Diesel Power Plant which can burden the community because of the high price of fuel oil. The existence of renewable energy sources such as Solar Power can reduce the cost of fuel oil for Diesel Power Plant, so Diesel Power Plant development planning needs to be integrated with Solar Power to form a hybrid microgrid. Blum et al. [8] states that the utilization of hybrid power plants between Solar Power and Diesel Power Plant in one region (Pulau Panjang) is able to produce optimal conditions with the contribution of using Solar Power by $67 \%$, as well as being able to reduce $\mathrm{CO}_{2}$ emissions by $617,208 \mathrm{~kg} /$ year. In addition to remote areas in Indonesia, Solar Power has also been built in many developing countries to electrify remote areas, such as in Kalasan Province, one of the remote areas in Thailand [9]. However, Solar Power as an energy source in remote areas has limitations that is only able to be used for lighting and low-power electrical equipment.

For several decades, Solar Power began to be considered in energy policymaking and was promoted to solve energy problems in remote areas. China and India are examples of some developing countries that are leading in terms of Solar Power installations [10]. Although not the only alternative, one solution meets the seventh point of the goal of sustainable development, namely ensuring access to affordable, reliable, sustainable and modern energy for all, especially people in remote areas who cannot yet fulfilled by the national electricity grid is the construction of renewable energy generation in off grid. One example of off-grid technology is Solar Power, which has been built in remote areas of developing countries to provide electricity to people who need to wait for years to be able to connect to the national electricity network [11]. However, high failures in the sustainability of renewable energy systems are also found, such as in Guatemala where $45 \%$ of solar power systems are no longer in operation and in Laos with $65 \%$ failures [12].

Having easy access to various types of energy sources and with low costs and government support will help people in remote areas maximize their potential [9]. Photovoltaic Solar

Table 1 Environmental Indicator

\begin{tabular}{lll}
\hline No Name & Definition \\
\hline 1 & Environmental Indicators $-\mathrm{CO}_{2}$ & $\begin{array}{c}\text { The amount of } \mathrm{CO}_{2} \text { in } \mathrm{kg} \text { produced by the power plant divided by the energy produced } \\
\text { during its useful life. } \\
\text { The amount of } \mathrm{NOx} \text { in } \mathrm{kg} \text { produced by the power plant divided by the energy produced } \\
\text { during its useful life. }\end{array}$ \\
$\begin{array}{l}\text { Environmental Indicator }-\mathrm{NOx} \\
\mathrm{The} \text { amount of } \mathrm{SO}_{2} \text { in } \mathrm{kg} \text { produced by the power plant divided by the energy produced } \\
\text { during its useful life. }\end{array}$ & $\begin{array}{l}\text { Environmental Indicators }-\mathrm{SO}_{2} \\
\text { The amount of Waste generation in kg produced by the power plant divided by the energy } \\
\text { produced during its useful life. }\end{array}$ \\
\hline
\end{tabular}

Source: Afgan and Carvalho [6] 
Power Plant has succeeded in improving the quality of life of the local community by increasing access to social services, such as health and education [13]. In addition, it is important to remember that the process of designing and planning a renewable energy system must not only meet the technoeconomic requirements, but must also pay attention to the environmental dimension [14]. However, each stakeholder in the renewable energy sector has its own views on the economic, social and environmental criteria of the development of renewable energy systems [6].

The government continues to build Solar Power especially in remote areas. This increase in Solar Power capacity is not always accompanied by an increase in the capacity of communities in remote areas, as a Solar Power manager. This has the potential to make Solar Power performance not optimal. Therefore, it is necessary to carry out an analysis of Solar Power sustainability in remote areas. The Solar Power sustainability factors analyzed consisted of technical, environmental, social and economic factors.

The sustainability of Solar Power has an effect on efforts to reduce $\mathrm{CO}_{2}$ emissions. Calculation of $\mathrm{CO}_{2}$ emission reduction is done through comparison of emissions produced from power plants other than renewable energy, using electricity emission factors. Through this research, the sustainability of Solar Power in remote areas will be analyzed as environmentally friendly energy built by the State Budget fund, including from environmental factors, namely as an effort to reduce $\mathrm{CO}_{2}$ emissions in these locations.

In line with research on the sustainability of renewable energy technologies that have been carried out by previous researchers, Evans (2008) delivered seven indicators of sustainability consisting of:

1) Electricity costs;

2) The GHG emissions shown in $\mathrm{CO}_{2}$ are equivalent, estimated based on the life cycle of renewable energy technologies, including $\mathrm{CO}_{2}$ equivalent emissions from the power plant manufacturing activity;

3) Availability of renewable energy technologies and their limitations for producing energy;

4) Efficiency of power plants;

5) Use of land needed to generate electricity from renewable energy;

6) Use of clean water needed for renewable energy power generation technology; and

7) Social impact.

According to Ranzanici [15], there are four sustainability factors of renewable energy systems, namely technical, social, economic, and environmental factors. The research is devoted to renewable energy types of Micro Hydro Power Plants. These four factors are divided into several indicators, namely:
1) Community Satisfaction: This indicator is used to assess the quality of energy provided in terms of blackout or power outages, installed capacity, voltage fluctuations. This indicator is related to the large number of people or families who are electrified, which is not the same as the initial planning, causing the low installed capacity for each family.

2) Civil Building Construction: This indicator is used to assess the quality of civil works of a Micro Hydro Power (MHP) including its safety aspects.

3) Electro-Mechanical Equipment: This indicator is used to assess the quality of electro-mechanical equipment, including those related to safety.

4) Repair time: This indicator is used to assess the ability of communities to overcome technical problems that have an impact on plant operations. This indicator indirectly aims to evaluate all factors related to the improvement or management carried out by the community, such as the availability of spare parts and technical personnel.

5) Community involvement: This indicator is used to assess the extent to which people are involved in Micro Hydro Power Plants operational activities and how to create a sense of ownership of Micro Hydro Power Plants or Pembangkit Listrik Tenaga Mikrohidro (PLTMH).

6) Organization: This indicator is used to assess the ability of organizations to manage renewable energy systems.

7) Extreme Weather Conditions: This indicator is used to assess extreme weather events that affect the operation of (PLTMH).

8) Competition for Water Use: This indicator is used to assess the availability of water for other users, for example for irrigation and pumping water by the community.

9) Financing Administration

This indicator is used to assess the adequacy of maintenance if an error occurs in the MHP system or other problems.

\section{0) Distance to the PLN Electricity Network}

This indicator is used to assess how close the electricity network is, given that people want to get electricity from the PLN network if possible.

This research aims to analyze the sustainability of Solar Power in remote areas as environmentally friendly energy built by the government funds (State Budget). This research further provides appropriate management recommendations.

\section{Method}

This research was conducted at the Solar Power Plant (Solar Power) located in Cibuyutan Village RW 08, Sukaraksa Village, Tanjung Sari District, Bogor Regency. Tanjung Sari 
District is one of the forty sub-districts in Bogor Regency which has an area of $129.98 \mathrm{~m}^{2}$ with a population of 51,716. The Solar Power Plant located in Kampung Cibuyutan RT 16 RW 08, Sukaraksa Village has a capacity of $15 \mathrm{kWp}$ (Ministry of Energy and Mineral Resources [2]). The Solar Power is a grant from the central government, in this case the Directorate General of New, Renewable Energy and Energy Conservation, Ministry of Energy and Mineral Resources which was built from the State Budget funds in the 2013 Budget Year.

The analytical method used in this research is the multidimensional analysis or Multi-Dimensional Scaling (MDS) using the Rapid Appraisal of Fisheries program (Rapfish) which is modified according to the research needs to become Rapid Appraisal of Renewable Energy (RapRE), namely computer-based statistical analysis using statistical software programs, which transforms each dimension and multidimensional and transforms each dimension of sustainability from an activity in a particular location ([16], Rahardjanto [17]). The flowchart of the method is illustrated in Fig. 1. The MDS method was used due to its ability to calculate various different dimensions of sustainability and generate an overall sustainability index. The division of index values and sustainability categories can be seen in Table 2 .

Through the analysis of the sustainability status of Solar Power with MDS using the computer software, an analysis of leverage, Monte Carlo analysis, determination of stress value, and the value of the coefficient of determination $\left(\mathrm{R}^{2}\right)$. All analyzes are in one package in the MDS program in software. Explanations and uses of the analyzes are as follows [18]:

a. Analysis of leverage: Leverage analysis is an analysis conducted to find out the attributes of each sensitive
Table 2 The Division of Index Values and Sustainability Categories

\begin{tabular}{ll}
\hline Index Value & Category \\
\hline $0-25$ & Not sustainable \\
$26-50$ & Not sustainable enough \\
$51-75$ & Quite sustainable \\
$76-100$ & Sustainable \\
\hline
\end{tabular}

Source: [16]

dimension to improve the sustainability status of Solar Power in remote areas as environmentally friendly energy. The most sensitive attribute is determined from the order of priority from the analysis results leverage with the view value Root Mean Square (RMS) on the X-axis ordination. Solar Power in remote areas.

b. Analysis of Monte Carlo: Analysis of Monte Carlo is the analysis used to estimate the effect of errors from the analysis process carried out, with a confidence level of 95\% whose value is expressed in the index of Monte Carlo.

c. Stress value and coefficient of determination $\left(\mathrm{R}^{2}\right)$ : Stress value is a value that reflects goodness of fit in MDS and serves to determine whether or not adding attributes need to accurately reflect the dimensions being investigated.

The steps taken in the analysis of the index and the sustainability status of Solar Power in remote areas as environmentally friendly energy are as follows [19]:

a. Determine the attributes on each dimension of sustainability which includes the environmental, technical, social

Fig. 1 Flowchart of Method

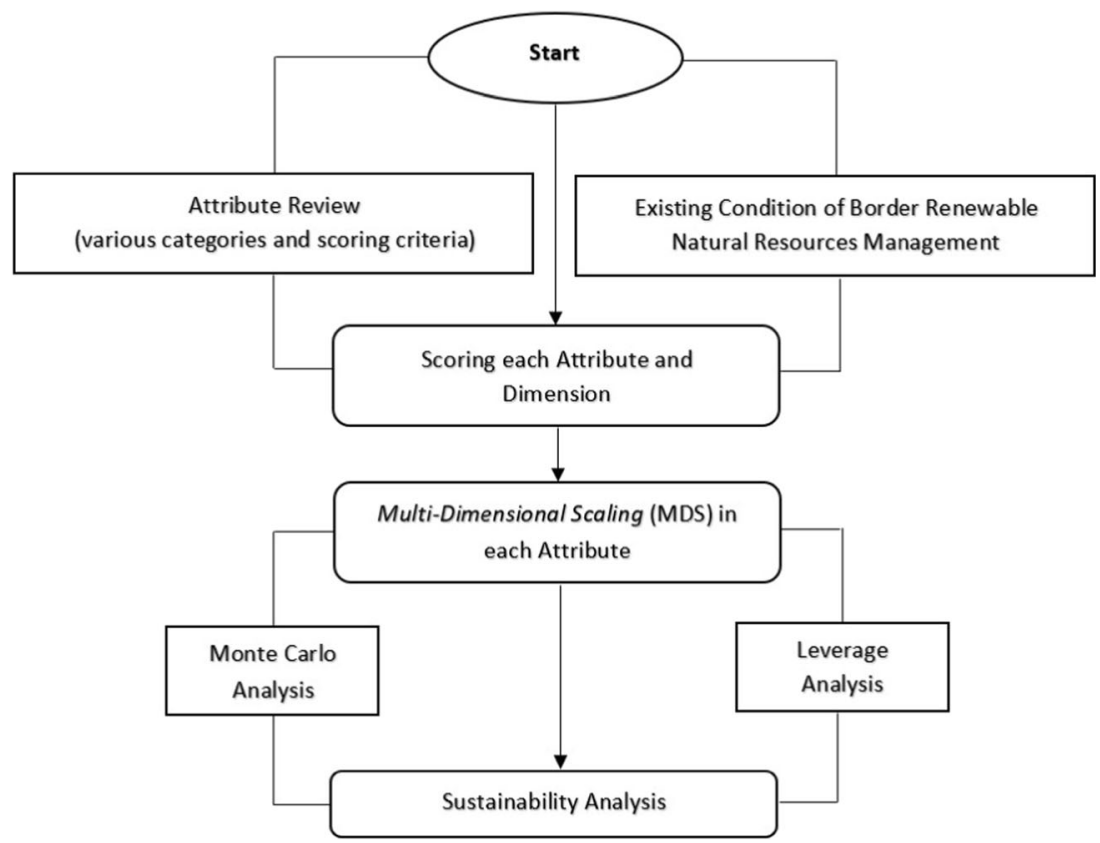


and economic dimensions. Determination of dimensions and attributes to be analyzed using the MDS method is the result of studies conducted by researchers and expert assessments. Attributes for each dimension of sustainability can be seen in Table 3 .

b. Conducting assessments and scoring on each attribute for each dimension based on the study of literature, the results of existing research conditions, and expert opinion. The scoring is done on an ordinal scale with a score range between 0 and 4 which is interpreted from good to bad or vice versa, according to the conditions of each attribute on each dimension.

c. Based on the results of scoring on each attribute, an MDS analysis with the RapRE tool was conducted to determine the index and the sustainability status of Solar Power in remote areas as environmentally friendly energy.

To see the most sensitive attribute (leverage factor) contributing to the sustainability index, a sensitivity analysis is carried out by looking at the form of change Root Mean Square (RMS) ordination on the $\mathrm{X}$ axis [16]. The final stage is the Monte Carlo analysis to determine the effect of errors in scoring. To determine the accuracy of the analysis, the determination of goodness of fit in MDS based on the S-Stress value calculated from the value of $S$ and $R^{2}$. A low stress value indicates good fit and a high $\mathrm{S}$ value indicates the opposite [19].

\section{Results and Discussion}

Based on observations in the field, sunlight appears from around 07.00 am to $16.00 \mathrm{pm}$. Rain often occurs in the afternoon with a duration of about $1 \mathrm{~h}$. The number of rainy days in Tanjung Sari District varies between 1 to 25 days per month, with a total of 133 rainy days in one year or around $36 \%$ in one year (Tanjung Sari Sub-District in Figures, 2016). However, this does not interfere with the absorption of solar energy in the solar power system because the rain that occurs only lasts about $1 \mathrm{~h}$.

Regarding the waste generated, based on the results of interviews with the PV-VP manager, until now there is no waste that needs to be managed because there is no replacement of PV-V components. The operation of Solar Power does not relatively result in complaints from residents related to environmental quality, such as noise, air pollution, and others.

Based on field observations, there is a guardrail at the PVVP location to prevent unauthorized people from entering the PV-VP system, especially in the generator house which contains batteries, inverters, solar charge controller, and other main components. However, at the time of the field observation, a number of domestic livestock belonging to residents who were eating wild grass around the solar module were found.
Table 3 Dimensions and Attributes of Solar Power Sustainability Index

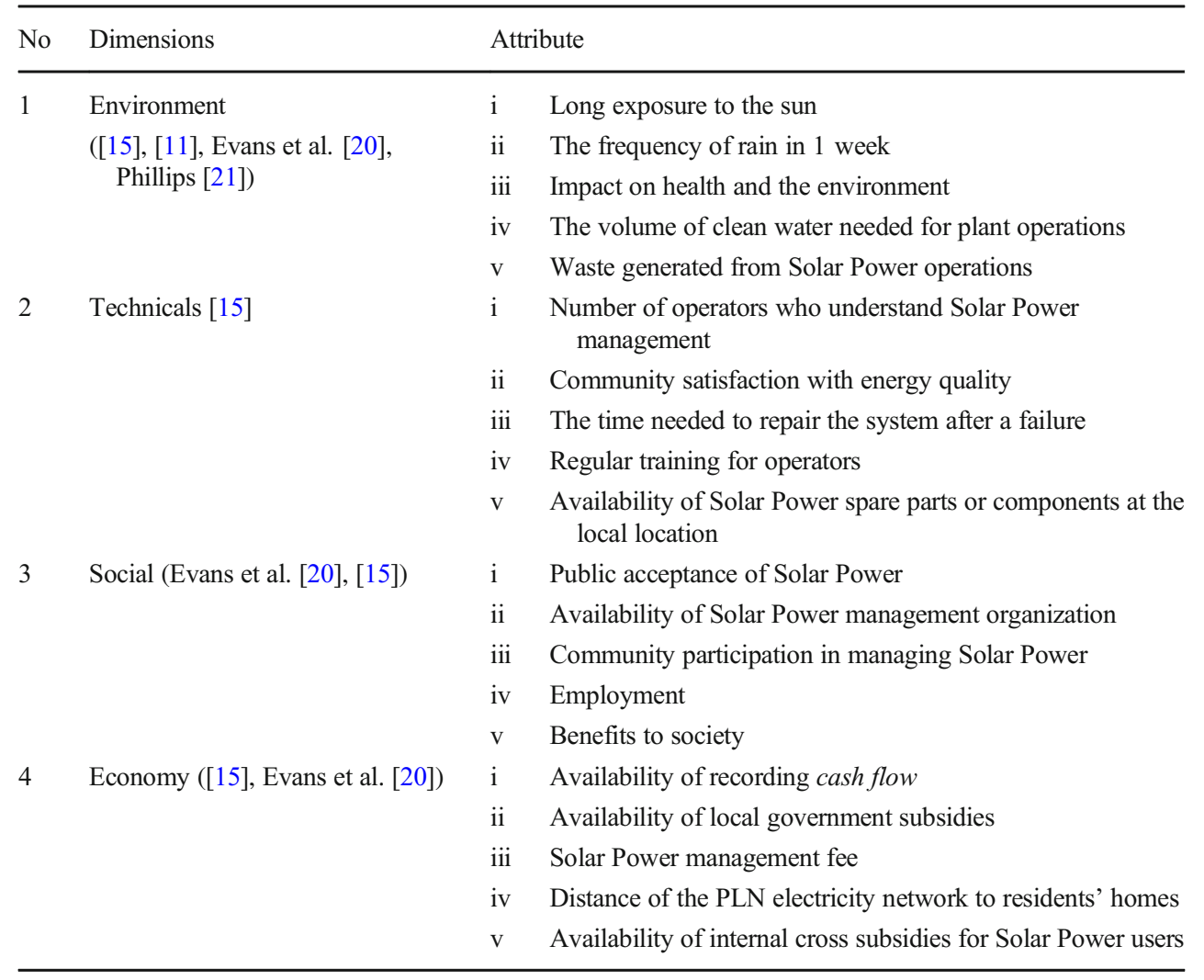


The Solar Power Plant in the research location has a capacity of $15 \mathrm{kWp}$ with a configuration of off grid. The main purpose of using Solar Power is for lighting at night. Therefore, Solar Power uses batteries to store electricity generated during the day. Furthermore, the use of electricity can be done at night, namely by utilizing electrical energy stored in the battery. Some of the main components of Solar Power in research sites and their specifications are as follows (Ministry of Energy and Mineral Resources [2]):

a. Solar module or photovoltaic $(P V)$ module: The solar module used is polycrystalline silicon with a minimum number of cells per module of 36 cells.

b. Valve-Regulated Lead-Acid (VRLA) Gel Battery: These batteries have a capacity of $1000 \mathrm{Ah}$ and $2 \mathrm{~V}$. respectively. The total number of batteries is 72 units.

c. Inverter: The number of inverters is 3 units with a capacity of $5 \mathrm{~kW}$ each.

d. Distribution panel: The number of distribution panels is 1 unit.

e. Pyranometer: Pyranometer is used to calculate the value of solar irradiation. The number of pyranometers used is 1 unit.

f. Remote Monitoring System (RMS): Remote Monitoring System used amounted to 1 unit. The purpose of installing RMS is to find out the energy produced by Solar Power and the energy used by the community. By using RMS, energy data on the PV-VP system in remote areas can be directly viewed through the system at the Directorate of New Energy and Renewable Energy, Ministry of Energy and Mineral Resources

The evaluation of Solar Power sustainability in Sukaraksa Village as an environmentally friendly energy was carried out using the MDS method using RapRE software (Rapid Appraisal of Renewable Energy Status) which has been used to assess the sustainability status of capture fisheries, and can be modified to assess the sustainability status of another system consisting of several dimensions.

\section{Solar Power Sustainability Index Data}

The results of multi-dimensional analysis using software RapRE produce Solar Power sustainability index value of 51.14. This value reflects that the sustainability of Solar Power in remote areas, in this case in Sukaraksa Village is quite sustainable in a multi-dimensional manner. This value is obtained based on an evaluation of 20 attributes covered in four dimensions, namely the environmental dimension (5 attributes), technical (5 attributes), social (5 attributes), and economy ( 5 attributes). The value of the sustainability index for each dimension and the results of the sustainability assessment can be seen in Table 4 and Table 5 . Based on Table 4, the overall sustainability index is 51.14 , meaning that the Solar Power is categorized as quite sustainable. The sustainability index for environment and technical dimensions are categorized as quite sustainable, meanwhile the sustainability index for social and economy dimensions are categorized as not sustainable enough. Every score result of all dimensions of the sustainability assessment is listed in Table 5. For example, for dimension "Long exposure to the sun", the score result is 2 , meaning that the exposure is about $5-8 \mathrm{~h}$.

\section{Sustainability Environmental Dimensions}

The analysis using MDS shows the value of the sustainability index for the environmental dimension of $61.78 \%$ with a fairly sustainable status. Sustainability index of the environmental dimension and its attributes can be seen in Figs. 2 and 3.

Based on the results of statistical attributes on the environmental dimension, it is known that the attributes that most play a role in the sustainability of solar power plant for the environmental dimension are the impact on the environment and health. In the operation phase, Solar Power has relatively no negative impact on the environment and health, in contrast to other types of electricity generation, especially non-renewable energy. This is in line with the results of studies of the use of solar power plants in remote areas in India which show that lighting from solar power plants has helped the community to overcome health problems that occur from the use of kerosene as fuel and burning candles in a closed room [22]. Research also shows Solar Power can minimize the risks and dangers arising from burning fossil fuels that increase GHG emissions that can result in global warming (Jagoo in [23]).

\section{Sustainability Technical Dimensions}

The analysis using MDS shows the value of the sustainability index for the environmental dimension of $47.93 \%$ with a fairly sustainable status. As shown in Figs. 4 and 5, he statistical attribute results on the technical dimension show that the attribute that has the most role in Solar Power sustainability for the technical dimension, namely the implementation of training for operators. This shows that by increasing the value of these attributes, the sustainability of the Solar Power technical dimension will also increase significantly. Operator training has a relationship with community satisfaction with the energy produced and the time needed to repair damage to the system, where if operator training is carried out routinely it will produce a reliable operator who is able to repair damage to the solar power system with a relatively short time, and increase community satisfaction This is in line with Mandelli 's (2016) study which states that technical training for Solar Power beneficiary communities is important to increase community capacity. 
Table 4 Sukaraksa Village Solar Power Sustainability Index

\begin{tabular}{|c|c|c|c|c|c|c|}
\hline \multirow[t]{2}{*}{ Dimensions of Sustainability } & \multicolumn{2}{|c|}{ Sustainability Index } & \multirow[t]{2}{*}{ Difference } & \multirow[t]{2}{*}{ Category } & \multicolumn{2}{|c|}{ Statistical Value } \\
\hline & MDS & Monte Carlo & & & Stress & $\mathrm{R}^{2}$ \\
\hline Environment & 61.78 & 62.14 & 0.36 & Quite sustainable & 0.16 & 0.94 \\
\hline Technical & 47.93 & 47.63 & 0.30 & Quite sustainable & 0.18 & 0.92 \\
\hline Social & 49.14 & 48.37 & 0.77 & Not sustainable enough & 0.15 & 0.94 \\
\hline Economy & 45.73 & 45.31 & 0.42 & Not sustainable enough & 0.16 & 0.90 \\
\hline Multi-dimensional & 51.14 & & - & Quite sustainable & - & - \\
\hline
\end{tabular}

\section{Sustainability of the Social Dimensions}

The analysis using MDS shows the value of the sustainability index for the social dimension of $49.15 \%$ with a fairly sustainable status. Sustainability index of the environmental dimension and its attributes can be seen in Figs. 6 and 7.

The results of the statistical attributes on the social dimension show that the attribute that has the most role in Solar Power sustainability for the social dimension is the availability of the management organization. This indicates that the existence of a good management organization will significantly increase the value of Solar Power sustainability in remote areas for the social dimension. According to Jorgensen [24], an assessment of the social dimension in the sustainability of renewable energy power plants needs to take into account the impact and the existence of organizations and systems in society.

The existence of a good management organization is expected to provide training to operators and the community related to Solar Power technology, be able to manage Solar Power finances transparently and optimally, and be responsible for managing the environment for waste that may arise from the Solar Power system. Because the existence of this management organization is indirectly related to other dimensions of sustainability, this attribute provides a large role for sustainability in the social dimension. In addition to the existence of the organization, the level of community trust in organizational leaders is also important for the sustainability of Solar Power [23].

\section{Sustainability Economic Dimension}

The analysis using MDS shows the value of the sustainability index for the environmental dimension of $45.73 \%$ with a less sustainable status. Sustainability index of the environmental dimension and its attributes can be seen in Figs. 8 and 9. Based on the results of statistical attributes on the economic dimension, the attributes that most play a role in the Solar Power sustainability for the economic dimension, namely the availability of government subsidies followed by the cost of managing Solar Power and the cost of managing Solar Power has to do with subsidies from the government.

As people in remote areas with relatively smaller incomes compared to people in urban areas, cost is certainly one of the important things in getting access to electricity. Although the cost of managing Solar Power is relatively cheap compared to other types of power plants. Subsidies from the government can be used to conduct technical training, replacing components that have quite expensive prices such as batteries, and others.

\section{Sustainability Analysis Solar Power}

The results of the analysis of Solar Power sustainability in remote areas using the MDS method in the form of a kite diagram can be seen in Fig. 10. Of the four dimensions of sustainability, the highest sustainability index values are (i) the environmental dimension of 61.78 ; (ii) social dimension of 49.14; (iii) technical dimension of 47.93; and (iv) economic dimension of 45.73. All three dimensions have a less sustainable status, while the environmental dimension is the only dimension of sustainability that has a fairly sustainable status.

The stress value of the MDS test results is quite low, ranging between $0.15-0.18$ and the coefficient of determination R2 varies between $0.90-0.94$. A relatively low stress value $(<0.25)$ indicates that the results of the analysis and attributes used are quite good in explaining the index and the status of sustainability (Reganold 2016).

After obtaining a sustainability index for each dimension, a Monte Carlo analysis was performed on the software. The results of the Monte Carlo analysis show that the Solar Power sustainability index value in remote areas is not much different from the results of the MDS analysis, which ranges from 0.30 to 0.77 . This indicates that errors in making scores of each attribute are relatively small, variations in scoring due to differences in opinion are relatively small, the process of analysis carried out repeatedly is stable, and errors in data entry and lost data can be avoided (Reganold 2016).

The Solar Power system in Sukaraksa Village is the off $t$, which is not interconnected with the PLN network. This 
Table 5 Sustainability Assessment Results

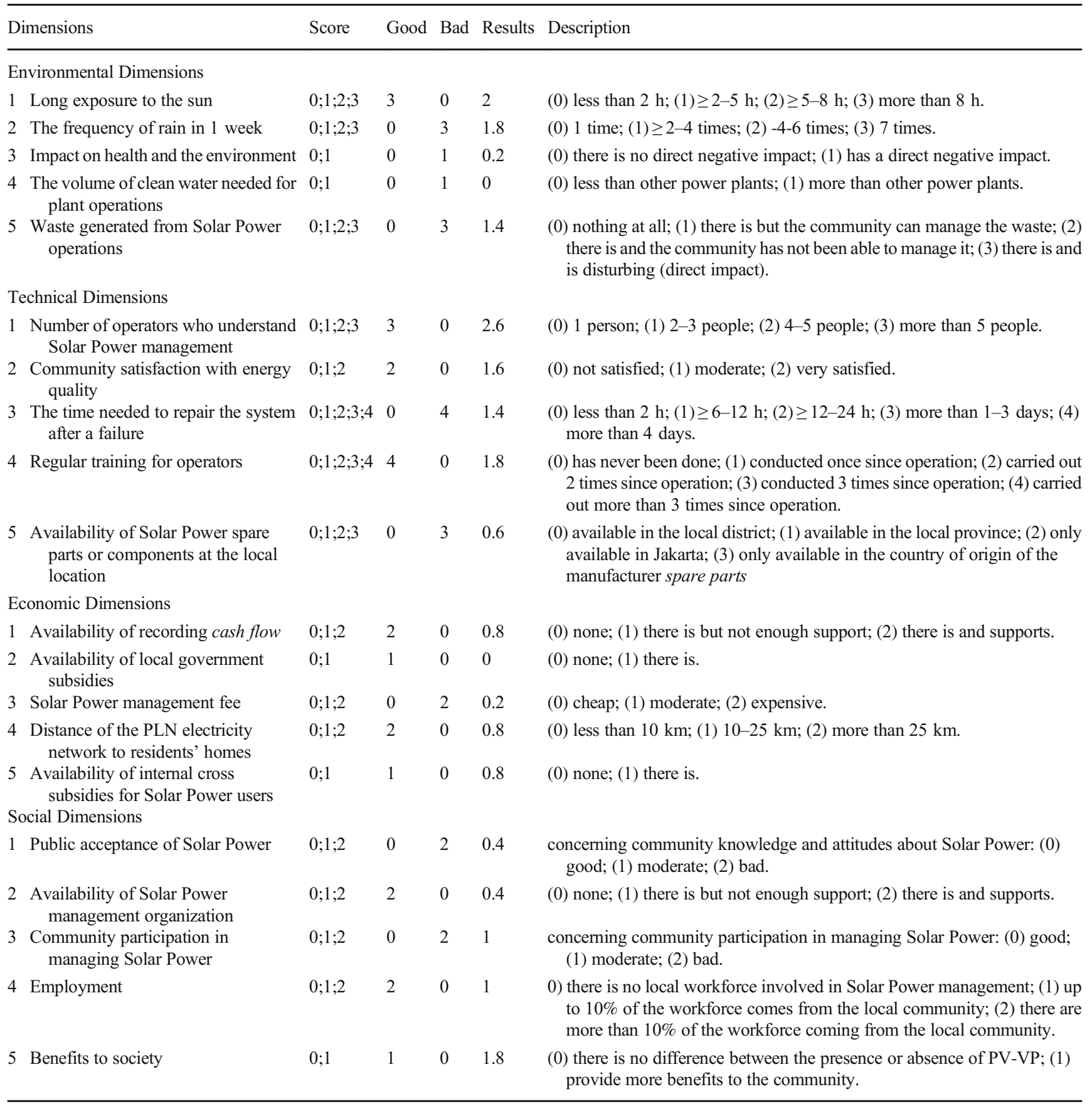

system uses batteries that are based on Government Regulation Number 101 of 2014 included in the category of dangerous and toxic materials. Therefore, the electrification ratio improvement program implemented through the Ministry of Energy and Mineral Resources needs to coordinate with the waste recycling program with the Ministry of Environment and Forestry as the main stakeholder. In locations where there is no recycling program, arrangements need to be made to provide education to the community and to require safe management of dangerous and toxic materials waste [25].

Viewed from the environmental aspect, although Solar Power can be said to be good because of the continuous availability of solar energy, the location of the Solar Power also needs to be properly guarded so as not to be entered by residents' livestock. The guardrail at the Solar Power location must be completely closed and locked tightly to avoid the entry of livestock or unauthorized persons. The entry of 
livestock and unauthorized people can risk disrupting Solar Power operational activities and endanger yourself. In addition, weeds need to be routinely cut around the Solar Power location, making it easier for operators or officers who are monitoring. Weeds that grow to a height that exceeds the height of the solar module can also block the received solar energy so that it will reduce the electrical energy generated [26].

Research in North Carolina reveals the collaboration of local farmers with Solar Power developers to create agricultural solutions for managing vegetation on Solar Power sites [27]. It was stated that the Solar Power developer taught local breeders to manage vegetation using their livestock, which is to let the goats eat grass around the project site so that the grass does not get long and covers the solar panels. This can also be applied in Sukaraksa Village. However, livestock that enter the project site still need supervision so as not to disturb and damage the Solar Power components.

The average energy produced from Solar Power is 8.93 $\mathrm{kWh}$ with an average use of $8.68 \mathrm{kWh}$ (Ministry of Energy and Mineral Resources [2]). The use of energy has started since 17.00 but with a relatively small amount. The peak energy use is from 18:00 to 20:00. This is in line with the results of the questionnaire distributed to residents, where Solar Power was only used in the afternoon until the evening. Based on these data, the energy produced by Solar Power is still able to meet the needs of citizens.

The electricity needs used by residents of Sukaraksa Village include lights, television, mobile phones, and some residents have radios and DVDs. Despite the benefits of Solar Power, its use can only be used at night for a few hours. The community hopes that Solar Power can be used all day, or at least since sunset at 18:00 until dawn at 05.00 where the village is dark if there are no lights. Therefore, the manager is expected to be able to find out the amount of energy entering, so that it can estimate the optimal use of Solar Power for the community.

Solar Power development planning in remote areas needs to be done by looking at the potential of solar energy in the location and taking into account the minimum needs of rural communities [28]. If the government does not pay attention to these two aspects, it is feared that the community will not be satisfied with the quality of electricity received and will be related to the sustainability of Solar Power in remote areas as environmentally friendly energy.

Another challenge related to the sustainability of smallscale Solar Power in remote areas is the lack of knowledge about the supply and demand for electricity in remote areas [29]. However, these challenges can be overcome by conducting a survey of the electricity needs of remote areas. In general, electricity needs in remote areas are only used for lighting and with relatively small amounts, so the calculation of predictions of electricity demand is relatively not as complicated as in areas where the type of electrical equipment usage varies greatly.

Solar irradiation is the main criterion in the construction of solar power plants, especially those that are communal and large scale because the amount of solar energy surrendered will greatly affect the production of electrical energy (Garni 2018). Some of these criteria need to be considered by the central government in planning Solar Power development in remote areas so that Solar Power is able to produce optimal energy for people's lives.

Solar Power Plants which have unlimited energy sources during the sun also have some challenges in developing them. According to Gebregiorgis [13], some of the challenges identified in the Solar Power development were generally related to sustainability issues, such as issues related to maintenance, lack of access to Solar Power spare parts, lack of technical ability to operate the Solar Power system, lack of support from related parties in this case the government, as well as financial challenges for people in remote areas.

A renewable energy system, in this case Solar Power, is said to be sustainable if in the long term it is able to reduce the negative impact on the environment and increase opportunities in the economic and social development of its people. Therefore, renewable energy technology must be able to meet three dimensions of sustainable development [30], namely: (i) environmental dimension, by reducing negative impacts on the environment, reducing GHG emissions, and reducing the
Fig. 2 Attributes of Environmental Dimensions

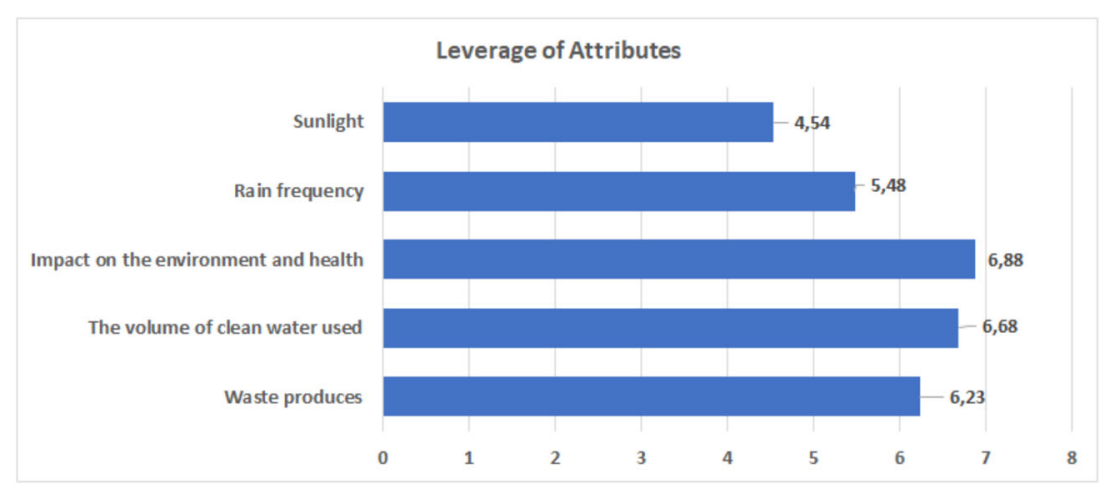


Fig. 3 RapRE Results of the Environmental Dimension

\section{RAP-RE Ordination}

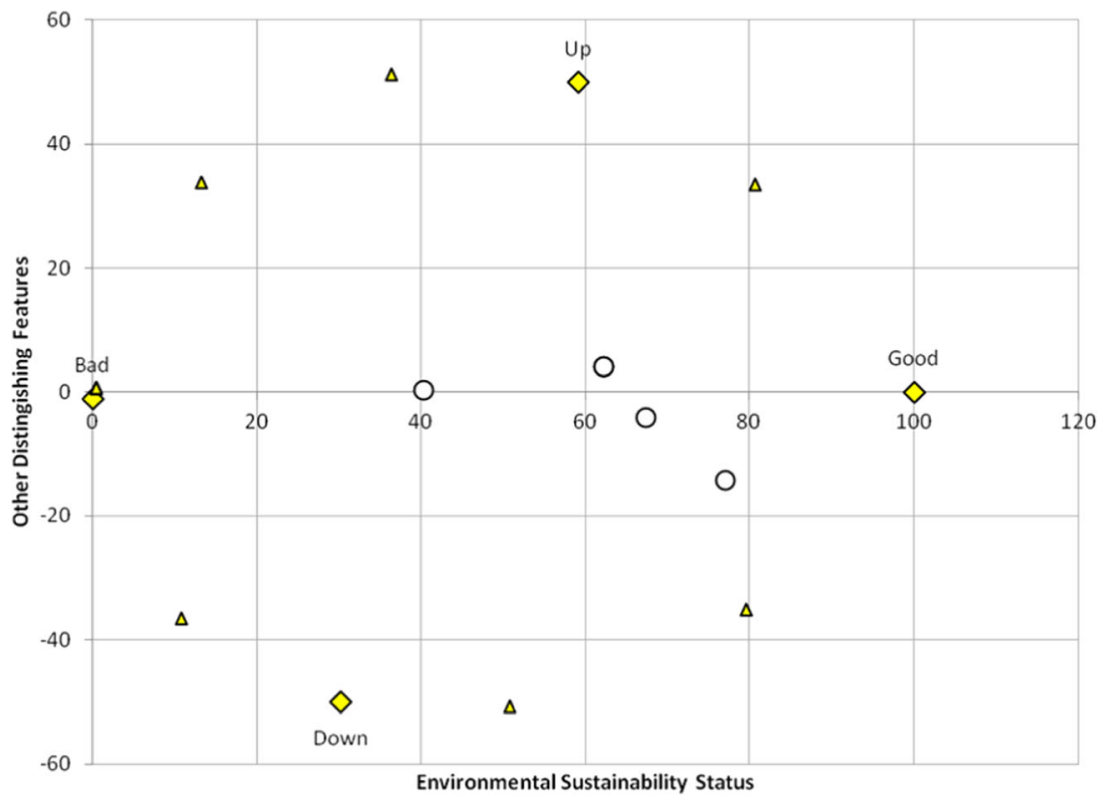

use of fossil energy; (ii) dimension (ii) social dimension, by being able to meet basic needs without having a negative impact on people's health and human life; (iii) economy, by reducing the consumption of fossil fuels which have high prices. To maximize the long-term sustainability of Solar Power off grid in the long term, the project design needs to ensure the involvement of key stakeholders in the Solar Power supply chain, such as energy consumers or the community, manufacturers or repair of spare parts, project financing institutions, and government [25].

The main component of solar panels is silica crystals, which are required to pass the Toxic Leaching Characteristic Procedure (TCLP) test to ensure that these components do not fall into the Hazardous and Toxic Material (B3) category. In addition to silica crystals, solar panels also consist of components that can be recycled, such as glass and aluminum, which make it possible to be recycled at the end of the use of Solar Power. One of the good practices is in the United Kingdom, where at present, The Solar Energy Industries Association (SEIA) has established a national solar panel recycling program that works closely with solar module manufacturers and developers to be able to create responsible recycling networks. Managing solar module waste [27]. The central government through the Ministry of Energy and Mineral Resources and the Ministry of Environment and Forestry can study this program and start trying to apply it to Solar Power especially those built in remote areas to minimize waste generated when Solar Power is no longer in operation.

One of the main factors in Solar Power management is ensuring that solar energy can be absorbed by the solar module optimally so that it can produce electrical energy that is also optimal. Dust, other objects, and shadows that cover the solar module will reduce the ability of the solar module to absorb solar energy. Therefore, the management must always ensure that the solar module is clean and not covered by other objects or shadows. Cleaning the solar module is enough to do with clean water that is splashed on the top surface of the solar module. Based on interviews with managers, cleaning solar modules has never been done due to lack of knowledge and the assumption that cleaning is not necessary because of the rain that almost every day that wet and clean the solar modules.
Fig. 4 Technical Dimension Attributes

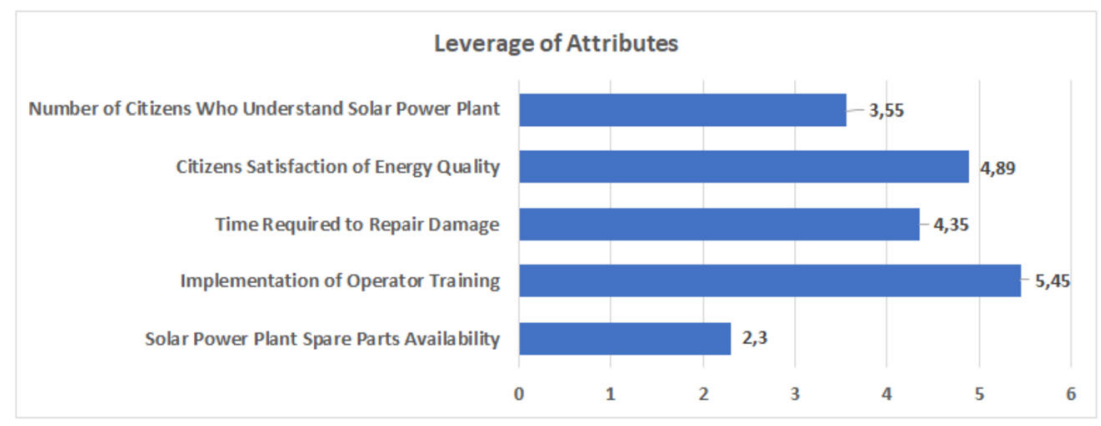


Fig. 5 RapRE Technical Dimension Results
RAP-RE Ordination

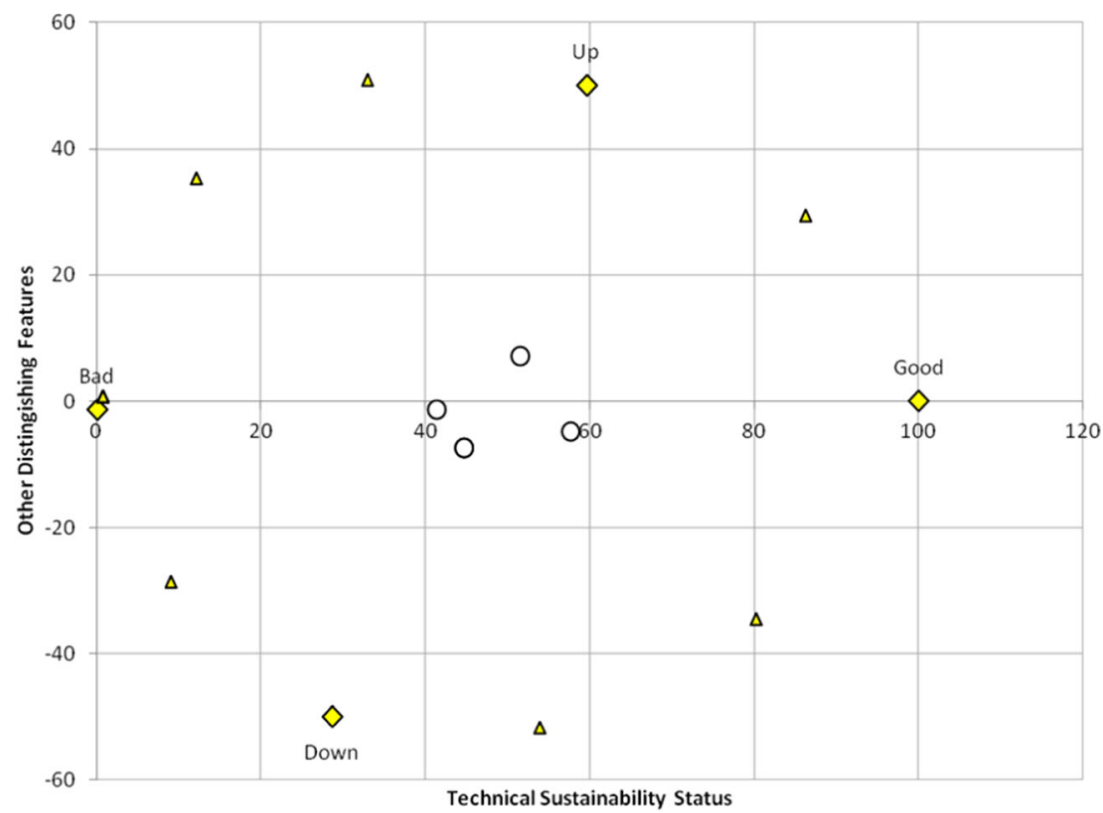

At the end of 2017 the central government through the Ministry of Energy and Mineral Resources has compiled Operation and Maintenance Guidelines for Solar Power Off Grid which can be used as a reference in maintaining Solar Power in remote areas. However, the guidelines have not been disseminated to Solar Power operators in remote areas, including in Sukaraksa Village. Lack of management knowledge on cleaning solar modules can occur due to suboptimal training that has ever been provided. Since it was built in 2013, the manager has only received one training from the central government, which is held by the Solar Power construction contractor. The training was only conducted for three managers, where at present one of them is no longer in Sukaraksa Village. In addition, there was no initiative from the management to transfer knowledge to other village communities.

When viewed from the educational background of villagers, the majority only attend school up to elementary school level and only $1 \%$ of respondents attend school up to senior high school. However, it is unfortunate that $1 \%$ of respondents, who have the potential to capture information better were not involved in the training. Based on the results of the questionnaire distribution, $10 \%$ of respondents were interested in participating in training related to Solar Power. But the training has never been done again. Local governments need to follow up on this by compiling work programs, one of which is providing training to remote area communities related to Solar Power technology and its management.

The off grid electrification project through renewable energy requires more preparation than the on grid project. It is necessary to make a profile of the will and ability to pay for electricity by the community through surveys, calculation of resources for power plants, and training of community leaders [25]. Related to the willingness and ability to pay, it is known that the majority of the community has the willingness to pay contributions for the management of solar power plants to be sustainable. However, contributions from the community alone are still not enough, considering that payments are not made routinely.

Local governments need to provide subsidies for Solar Power management, especially in replacing Solar Power components in large quantities and at quite expensive prices, such as batteries. The government can also provide grant assistance
Fig. 6 Social Dimension Attributes

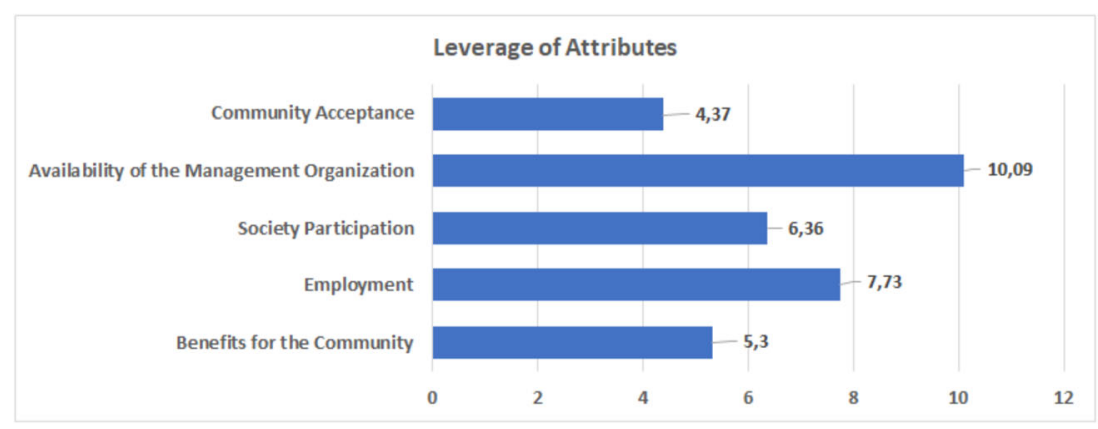


Fig. 7 RapRE Results of the Social Dimension
RAP-RE Ordination

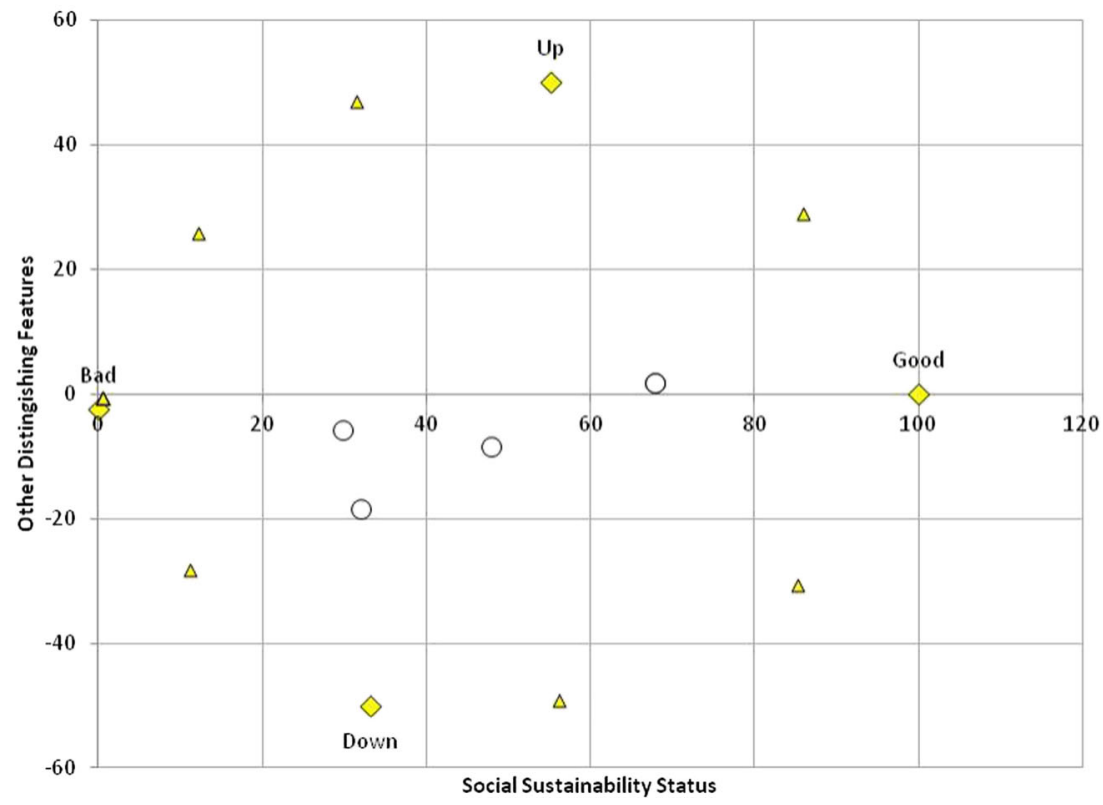

in the form of productive tools that can be used by villagers to improve their economy, for example refrigerators to make and sell ice cubes, dryers for agricultural materials to make them more durable, and others. Access to electricity is able to make use of electronic equipment and devices by small and medium enterprises and is able to produce a significant increase in productivity (Valodka and Valodkiene [31]). Small investors engaged in the energy sector are also important to be involved in achieving decentralized energy production based on renewable energy and in parallel able to increase energy security [31]. But keep in mind that the use of productive tools to improve the quality of life of the community also needs to be accompanied by the availability of electricity from the Solar Power.

One of the weaknesses in the management of Sukaraksa Village Solar Power is the absence of a management organization. The community chaired by the Chairperson needs to form and make the Solar Power management organization a formal organization that is able to accommodate complaints and input from the public regarding the use of Solar Power. The community is also expected to be able to participate in sustainable Solar Power management even though they are not incorporated in the management organization.

Although the current community participation in Solar Power management is only in the form of fee payments, it is hoped that with the Solar Power management organization community participation can be more varied. Some examples of community participation in managing Solar Power can be done through regular payment of fees, supervision of Solar Power financial reports, security of surrounding locations, and so on. Project safety is important in the sustainability of solar power plant in remote areas considering that most projects experience vandalism and theft on some of the solar power plant components [23]. Just like the on grid electrification program which currently still receives subsidies from the government, the off grid electrification program also requires subsidies from the government.

Compared with electricity customers on grid from PLN, the population of electricity customers off grid in remote areas generally has lower incomes and types of settlements are scattered [25]. Technology with a mini grid configuration has a higher investment cost but lower fuel and operational
Fig. 8 Attributes of Economic Dimensions

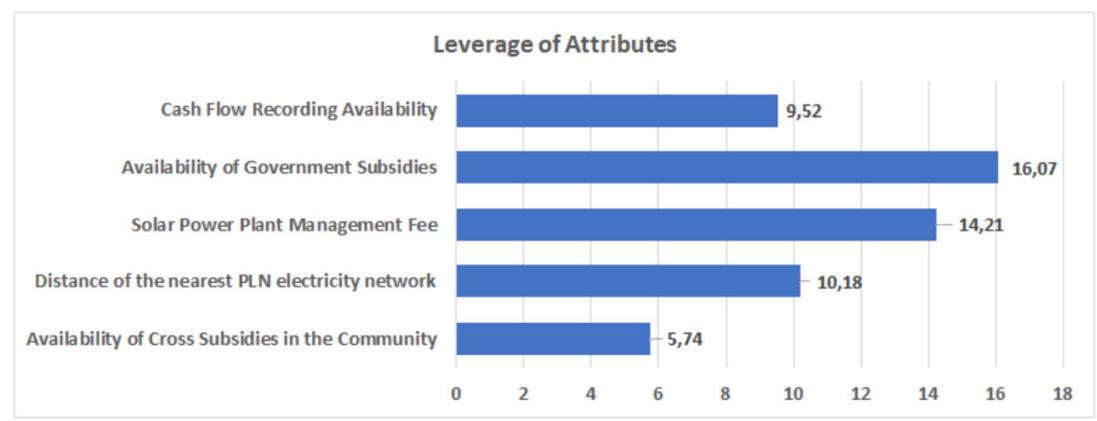


Fig. 9 RapRE Economic Dimension Results
RAP-RE Ordination

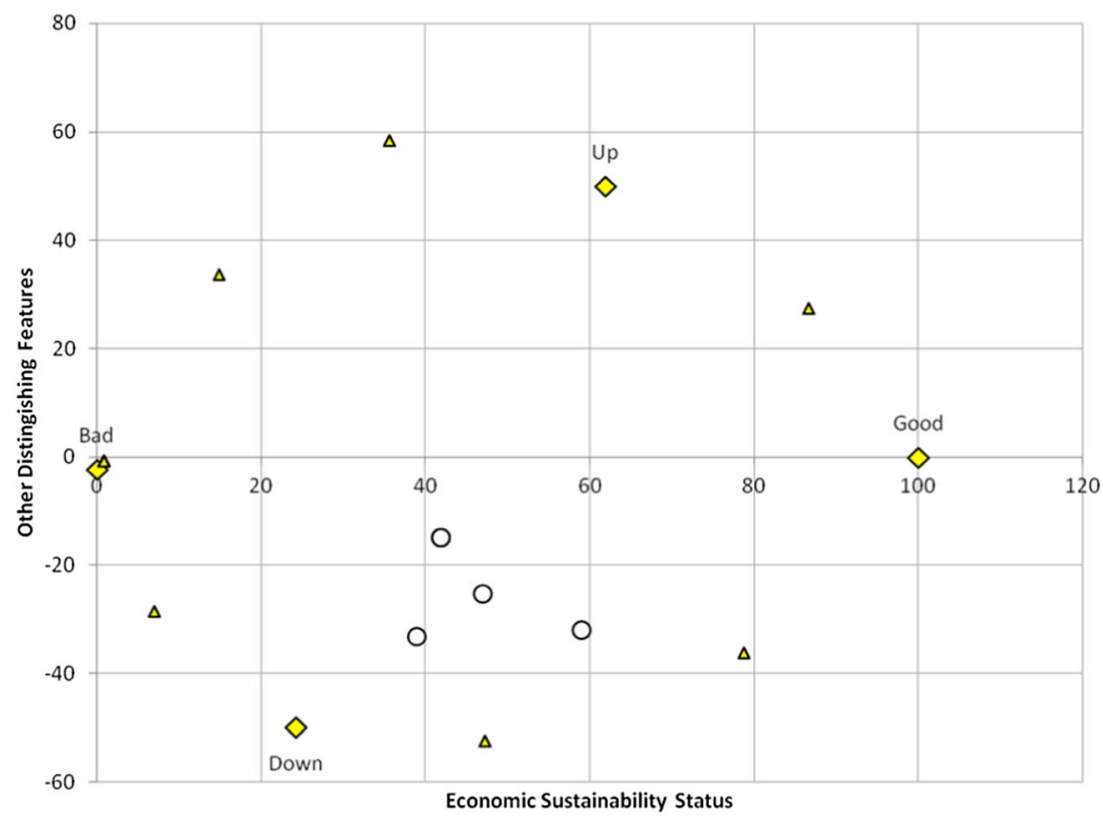

costs when compared to other fuel-based power plants. However, energy costs can exceed people's ability or willingness to pay. In such a case, subsidizing consumers off grid can help with the cost of access to electricity. Public welfare will increase with the intervention or subsidy for off grid electricity higher than the long-term costs (Barnes and Halpern [32]).

The condition of Solar Power is site specific, which means that the condition will depend on the location of the Solar Power. This research was conducted in a remote area in the form of the highlands with the majority of the community's livelihoods being farming. Remote Solar Power located in the lowlands or coastal areas certainly have different characteristics from Solar Power located in the highlands. Examples are Solar Power components that are likely to experience corrosion due to sea winds containing salt vapor, as well as Solar Power components whose performance is sensitive to changes

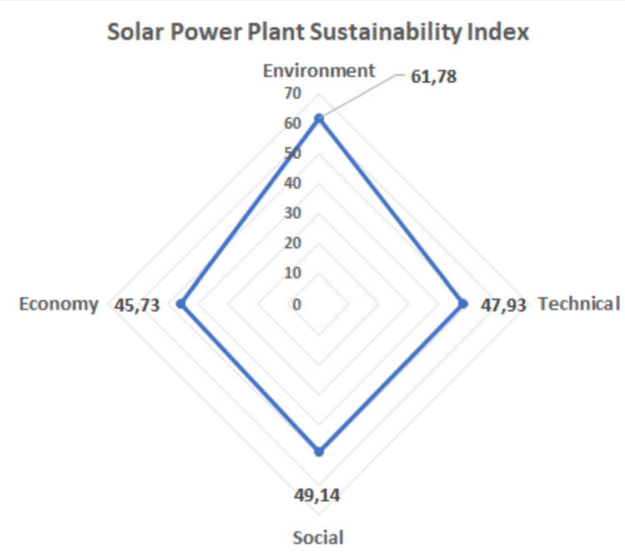

Fig. 10 Solar Power sustainability index diagram in temperature, or other conditions. Therefore, further research is needed on the sustainability of solar power plants in other remote areas, for example in coastal areas, considering that Indonesia has a long coastline with large solar energy potential.

\section{Conclusion}

The Solar Power sustainability index in Desa Sukaraksa is 51.14 with the category quite sustainable for each dimension sorted from the highest value which is (i) the environmental dimension of 61.78 with a moderately sustainable status; (ii) technical dimension, which is 47.93 with a less sustainable status; (iii) economic dimension of 45.73 with a less sustainable status; and (iv) social dimension that is 49.14 with less sustainable status.). Maximizing the involvement of Solar Power beneficiaries as early as possible is very important for the sustainability of Solar Power off grid. Some activities that can be done for example are the introduction of the Solar Power program, regular meetings with community leaders, and group meetings. Local governments, either through the Village Head or the provincial EMR Office have the responsibility in facilitating to provide the community with a framework and support for building a sustainable renewable energy infrastructure. The community can play an important role in the decentralization of energy systems, especially environmentally friendly renewable energy. Decentralized energy systems are in many cases more resistant to climate change and disasters and more reliable than centralized systems. 
Acknowledgments This research is funded by the Grant of Indexed International Publication for Final Projects of Students (PITTA) from DRPM Universitas Indonesia with contract number 2578/UN.R3.1/ HKP.05.00/2018.

\section{References}

1. Deputy Strategic Plan for the Coordination of Energy, Natural Resources and Environmental Management (2015) Rencana Strategis Kementerian Energi dan Sumber Daya Mineral 20152019 (Strategic Plan of the Ministry of Energy and Mineral Resources 2015-2019). Jakarta

2. Ministry of Energy and Mineral Resources (2016) Statistik Energi Baru, Terbarukan, dan Konservasi Energi (Renewable Energy and Energy Conservation Statistics). Jakarta

3. Sharma NK, Tiwari PK, Sood YR (2012) Solar energy in India: strategies, policies, perspectives and future potential. Renew Sust Energ Rev 16(1):933-941

4. Veldhuis AJ, Reinders AH (2013) Reviewing the potential and cost-effectiveness of grid-connected solar PV in Indonesia on a provincial level. Renew Sust Energ Rev 27:315-324

5. Chu S, Cui Y, Liu N (2017) The path towards sustainable energy. Nat Mater 16(1):16-22

6. Afgan HM, Carvalho GM (2004) Sustainability assessment of hydrogen energy system. International journal of hydrogen energy 29: 1327-134af2

7. Bayrak G, Kabalci E (2016) Implementation of a new remote islanding detection method for wind-solar hybrid power plants. Renew Sust Energ Rev 58:1-15

8. Blum UN, Wakeling SR, Schmidt ST (2013) Rural electrification through village grids - assessing the cost competitiveness of isolated renewable energy Technologies in Indonesia. Renew Sust Energ Rev 22:482-496

9. Saetan S, Veerawattananon V, Suttiprapa T (2015) Development of renewable energy for rural economy households with the blended and participatory learning processes in Kalasin Province in Thailand. Int Forum Teach Studies 11(1-2)

10. Tucho GT, Nonhebel S (2017) Alternative energy supply system to a Rural Village in Ethiopia. Energy, Sustainability and Society 7:33

11. Feron S (2016) Sustainability of off-grid photovoltaic Systems for Rural Electrification in developing countries: a review. Sustainability 8

12. International Renewable Energy Agency (IRENA) (2016) Accelerating off grid renewable energy. International Off Grid Renewable Energy Conference

13. Gebregiorgis G (2015) Engendering energy in Ethiopia: the role of solar energy in improving rural Women's socio-economic conditions in Tigrai region. Int J Sociol Anthropol 7(1):8-20

14. Akinyele DO (2017) Environmental performance evaluation of a grid-independent solar photovoltaic power generation (SPPG) plant. J Energ 130:515-529

15. Ranzanici A (2013) Sustainability comparison between EnDev and non EnDev micro hydro power (MHP) in Indonesia - analysis of the long term technical, social, environmental, and economic sustainability of the rural energy infrastructure of MHP in Indonesia. Deutsche Gesellschaft für Internationale Zusammenarbeit (GIZ), Jakarta
16. Syaifudin A, Carsjens GJ (2018) Exploring farming strategies in a metropolitan area: case study of inland aquaculture in Bogor regency. In IOP Conference Series: Earth and Environmental Science 202(1):012026

17. Rahardjanto A (2015) Model Partisipasi Masyarakat pada Konservasi DAS Hulu Berbasis Bioindikator Sebagai Upaya Pengelolaan Sungai Berkelanjutan (Community Participation Model in Upstream Watershed Conservation Based on Bioindicators for Sustainable River Management). School of Environmental Science, Universitas Indonesia, Jakarta

18. Reganold JP, Wachter JM (2016) Organic agriculture in the twentyfirst century. Nat Plants 2(2):15221

19. Juwana I, Muttil N, Perera BJC (2016) Application of west java water sustainability index to three water catchments in west java, Indonesia. Ecol Indic 70:401-408

20. Evans A, Strezov V, Evans TJ (2009) Assessment of sustainability indicators for renewable energy technologies. Renew Sust Energ Rev 13:1082-1088

21. Phillips J (2013) Determining the sustainability of large-scale photovoltaic solar power plants. Renew Sust Energ Rev 27:435-444

22. Buragohain $T$ (2012) Impact of solar energy in rural development in India. Int J Environ Sci Development 3(4):334-338

23. Matungwa B (2014) An analysis of PV solar electrification on rural livelihood transformation - a case of Kisiju-Pwani in Mkuranga District, Tanzania. University of Oslo, Norway

24. Jorgensen SE (2010) Ecosystem services, sustainability and thermodynamic indicators. Ecological Complexity 7(3):311-313

25. World Bank (2008) Designing sustainable off-grid rural electrification projects: principles and practices. World Bank, Washington

26. Pacudan R (2016) Implications of applying solar industry best practice resource estimation on project financing. Energy Policy 95: 489-497

27. Givens R, Nicholas (2017) The environmental review of solar farms in the southeast U.S - Maximizing Benefits \& Minimizing Impacts to drive smart, sustainable development of solar power. Southern Environmental Law Center. Chapel Hill

28. Cicih LHM, Herawandih E (2018) The impact of micro-scale solar power supply for rural households, in Central Kalimantan Province, Indonesia. ASEAN J Commun Engagement 2(2):265-280

29. Aberilla JM, Gallego-Schmid A, Stamford L, Azapagic A (2020) Design and environmental sustainability assessment of small-scale off-grid energy systems for remote rural communities. Appl Energy 258:114004

30. Luong S, Liu K, Robe, J (2016) Sustainability Assessment Framework for Renewable Energy Technology, accessed in https://www.reading.ac.uk/web/files/tsbe/Luong_TSBE_ Conference_Paper_2012.pdf

31. Valodka I, Valodkiene G (2015) The impact of renewable energy on the economy of Lithuania - 20th international scientific conference economics and management. Procedia - Social Behav Sci 213: $123-128$

32. Barnes DF, Halpern J (2000) Subsidies and sustainable rural energy services: can we create incentives without distorting markets? World Bank Group, Washington

Publisher's Note Springer Nature remains neutral with regard to jurisdictional claims in published maps and institutional affiliations. 